\title{
The Effect of Verbal Skills and Self-Placement on Students Acceptance of Community Service Program in East Towuti
}

\author{
Muhammad Guntur ${ }^{1 *}$, Hengki Wijaya ${ }^{2}$, Zulfah $^{3}$, St. Maria Ulfah ${ }^{4}$, Bahartiar $^{5}$ \\ \{'muh.guntur20@yahoo.co.id\} \\ ${ }^{1}$ Institut Agama Islam Negeri Palopo, Indonesia \\ ${ }^{2}$ Sekolah Tinggi Filsafat Jaffray Makassar, Indonesia \\ ${ }^{3}$ Sekolah Tinggi Agama Islam Darud Dakwah Wal-Irsyad Maros, Indonesia \\ ${ }^{4}$ Universitas Negeri Makassar, Indonesia \\ ${ }^{5}$ Universitas Muhammadiyah Kendari, Indonesia
}

\begin{abstract}
The community service program is an activity for undergraduate students in several universities. This activity combines the implementation of education and learning in Higher Education with the method of providing learning experiences and working for students in community empowerment activities. Students who carry out fieldwork need language skills, and communicate well; besides that, self-placement in the community is also essential. This type of research is associative research using path analysis techniques (path analysis). The sampling technique with probability sampling, the samples into research was 30 respondents. Data collection in this study used a questionnaire. Based on the results of data analysis shows the correlation coefficient of verbal ability to self-placement is equal to 0.776 and has a positive value or an influence of $77.6 \%$. The verbal ability correlation coefficient on the level of student acceptance is positively valued at 0.387 or has an effect of $38.7 \%$. The value of the impact of selfplacement on the level of student acceptance is 0.348 . Verbal ability and self-placement influence student acceptance rates of 0.691 or an effect of $69.1 \%$. It can be concluded that verbal ability and self-placement affect the level of student acceptance.
\end{abstract}

Keywords : Verbal Skills, Self-Placement, Students

\section{Introduction}

The Tuwoti Subdistrict, East Luwu Regency is one of the areas that has been the target of the Community Service Program, especially students from IAIN of Palopo. This area is a transmigrant area consisting of various languages, ethnicities, religions, and cultures. The differences that are owned as the target of the placement cannot be denied that social upheaval occurs. For the community, Tuwoti conflict is something that cannot be separated into community life. Many community groups still prioritize their main ethnic identity. In reality, this still happens in Tuwoti. Although said so, on the other hand, not all community groups have the characteristics of hot ethnicity (accentuating ethnic identity), but some are more tolerant of one another. About the issue of community social integration, excellent communication is one solution to the problem. It should be noted that social inclusion does not 
occur scientifically, but requires a supporter to help solve problems that occur. Students have an essential role in this matter. One of the things you need to have as a student is language skills and excellent communication. Communication has many forms, one of which is verbal communication skills. Ronda and Salong revealed that the elements of communication in building public relations must be synergistic, such as the role of the message, the role of the communicator, the position of the communicant, the part of the way to convey, the role of results, and the role of feedback[1].

Verbal ability is the ability to arrange thoughts clearly and be able to use this ability to competently through words to express these thoughts in speaking, reading, and writing[2]. The community responds to student ability in The community service program. The knowledge obtained by students is still considered less applicable to the problems that exist in society. There are also those who think that students have all the abilities and solutions needed by them. The ability to place or position yourself is also one of the keys to success in the association. Understanding one's position makes a person skilled in behaving, speaking, and acting so that in interactions with anyone, someone is always able to make those who are connected with him happily. They are also able to treat other people with dignity, even though the respected person tries to eradicate his pride. People who are good at positioning themselves can determine the best attitude, in interaction with anyone, anywhere, and whatever the atmosphere that underlies the communication. The purpose of this study was to assess the effect of verbal abilities and self-placement on student acceptance.

\section{Literature Review}

\subsection{Verbal Ability}

Humans can think well and even abstractly because of their ability to speak. Thanks to language, people can think continuously, regularly, and systematically. Thinking is a series of personal cognitive processes (informative processing) that take place during the occurrence of a stimulus until the emergence of a response. Verbal ability refers to a person's ability to put ideas into words, both oral and written. Verbal ability also includes the ability to arrange words in a coherent way. Verbal ability is usually shown as the ability to write and speak well[3]. In doing thinking activities, one uses verbal symbols (words) and grammar laws (grammar) to combine words in a sentence. The ability to think someone determines and at the same time can be understood from their language skills. Conversely, a person's language skills are a reflection of one's thinking ability. The results of research by Andreou et al., Low verbal language abilities are also influenced by the relationship between language development and self-control[4].

\subsection{Self-placement}

The ability to place oneself is one of the keys to success in the association. Understanding one's position makes a person skilled in behaving, speaking, and acting. Blakesley explained that placing yourself helps students to make future decisions by learning from past experiences[5]. The ability to place oneself can be defined as the ability to adapt, adjust to the environment, especially the new environment to be a pleasant person. Because 
with this adaptability and self-positioning, someone will readily be accepted by people everywhere.

\subsection{Student Acceptance}

Maslow explained that placing self-acceptance, acceptance of other people, and the environment in the second place in the list of characteristics of people who are actualized (self-actualizing person) [6]. A healthy individual will show respect for himself and others, accept other people with limitations and weaknesses, the fragility of this individual is free with feelings of guilt, shame, and inferiority and will also be anxious about the judgment of others towards him. The concept of student acceptance starts from the idea of one's self-acceptance of himself, others, and the environment. Self-acceptance is related to a positive self-concept. A person with a positive self-concept can understand and accept facts that are so different from him. Maslow explained that placing self-acceptance, acceptance of others, and the environment in the second place in the list of characteristics of people who are actualized (self-actualizing person) [7].

Human needs form an "integrated hierarchy," where basic needs such as safety, ownership, connections, and self-esteem must be fulfilled to a certain extent so that one can move towards being all that is one's ability: self-actualization [8]. Kuprieieva revealed the structure of self-actualized personality has the subject of self-realization characterized by the primary role of the value of self-actualization, harmony of needs, abilities, and costs [9]. Selfacceptance is the extent to which a person can realize personal characteristics and use them in living his life. The attitude of self-acceptance is shown by someone's recognition of their strengths and accepting their weaknesses without blaming others and having a constant desire to develop themselves. The community acceptance can be anticipated from three perspectives, namely community acceptance of themselves, community acceptance of the community itself, and community acceptance of their environment. The relation between public acceptance of students in the Community Service Program will be strongly related to these three perspectives. Students who are by the concepts that are in the corner of their fields will be accepted by the community well whereas people who are considered not by the current idea will be rejected or difficult to accept by the community. The modern concept in the city is not limited to rules, ethics, habits, religion that develops in the community, but also includes the personal ideas of each community. The results of research conducted by Marthen that the reception of the surrounding community is quite harmonious; the surrounding community feels the presence of the campus has a positive impact on the environment. From this study, it was also found that the community can accept the presence of the university well because the campus community is always concerned and builds good cooperation with all parties [10]. Thus verbal ability, one's self-placement can affect self-acceptance by the people we serve.

\section{Research Methodology}

This type of research is associative or relationship research using path analysis techniques (path analysis) [11]. Path analysis is used to analyze the pattern of relationships between variables to determine the direct and indirect effects of a set of exogenous variables (verbal ability and self-placement) and endogenous variables (student acceptance level). The 
population in this study were all students studying at universities in the IAIN of Palopo. The sample in this study were students who had conducted real work lectures in Tuwoti District, East Luwu Regency. With sampling techniques with sampling probability, the samples taken were 30 respondents. The number of data samples is based on the standard error. The data obtained were analyzed using statistical analysis techniques, namely, descriptive and inferential statistical analysis. Descriptive statistics are statistics used to analyze data by describing or describing collected data as they are, without intending to make generally accepted conclusions. The investigation of direct effects and the indirect effects of the variables of this study used inferential statistics, namely path analysis.

\section{Result and Discussions}

Table 1. Verbal Ability, Self-Placement, and Students Admission

\begin{tabular}{lccc}
\hline Measurement Value & Verbal Ability & Self-Placement & Students Admission \\
\hline 1. Lowest value & 52 & 26 & 25 \\
2. Highest Value & 102 & 78 & 54 \\
3. Average Value & 80.80 & 5 & 38.47 \\
4. Variants & 214.78 & 255.45 & 65.84 \\
Standard deviation & 14.65 & 15.98 & 8.11 \\
\hline
\end{tabular}

Table 1 shows the descriptive analysis of students' verbal abilities according to the results of the study, obtained the lowest data 52 and the highest data 102, the average value of 80.80 , the variance of 214.78 , while the standard deviation or standard deviation is 14.65 . Self-placement obtained the lowest data 26 and the highest data 78, the average value of 52.17 , the variance of 255.45 , while the standard deviation or standard deviation amounted to 15.98. Furthermore, for the level of student acceptance, the lowest data is obtained 25 , and the highest data is 54 , the average value is 38.47 , the variance is 65.84 , while the standard deviation or standard deviation is 8.11 .

The analysis prerequisite test that will be carried out is the normality test and the linearity test. The normality test is carried out by one sample Kolmogorov Smirnov test [12] with a significance level of 0.05 . Based on the output of the normality variance test using the Kolmogorov Smirnov one-sample test, the significance value obtained was 0.766 . Because the significance value is more than 0.05 , it can be said that the data on verbal ability, selfplacement, and student acceptance rates are normally distributed. Furthermore, the linearity test is carried out on linear line equations of self-placement of verbal abilities (X2 over X1), student acceptance rates for self-placement ( $\mathrm{Y}$ on $\mathrm{X} 2$ ) and student acceptance of verbal abilities ( $\mathrm{Y}$ on X1).

The linearity of self-placement test on verbal ability (X2 over X1), shows that all prices of fcounts are 0.771 smaller than $\mathrm{f}_{\text {table }}$ of 4.182 with a probability of 0.700 higher than the significance level of 0.05 . The self-placement of verbal abilities (X2 over X1) is linear. Test the linearity of the level of student acceptance of self-placement (Y on X2). Indicates that all prices of $f_{\text {counts }}$ are 1.724 smaller than $f_{\text {table }}$ of 4.182 with a probability of 0.218 higher than the significance level of 0.05 . The level of student acceptance of self-placement ( $\mathrm{Y}$ on $\mathrm{X} 2$ ) is linear. The last linearity test is the level of student acceptance of verbal abilities (Y on X1), indicating that all prices of $f_{\text {counts }}$ are 0.663 smaller than $f_{\text {table }}$ of 4.182 with a probability of 
0.774 higher than the significance level of 0.05 . The level of student acceptance of verbal abilities (Y on $\mathrm{X} 1$ ) is linear.

\subsection{Partial hypothesis testing of verbal ability towards self-placement}

The statistical hypothesis that will be tested is the influence of verbal abilities on selfplacement. Based on the calculation results obtained by the value of tcount of 3.301 with significant value ( $p$-value) equal to 0.007 . Because $t_{\text {count }}(3.301)>t$ table $(2.048)$ then rejects (H0) and accepts the research hypothesis (H1), so that with a confidence level of $95 \%$ it can be concluded that verbal ability has a significant effect on self-placement.

\subsection{Partial hypothesis testing of the verbal ability to the level of student acceptance}

The second hypothesis to be tested is the effect of verbal ability on the level of student acceptance. Based on the results of the test obtained the value of $t_{\text {count }}$ of 3.465 with significant value ( $p$-value) equal to 0.006 . Because $t_{\text {count }}(3.465)>t_{\text {table }}(2.048)$ then rejects $(H 0)$ and accepts the research hypothesis (H1), so that with a confidence level of $95 \%$ it can be concluded that verbal ability has a significant effect on the level of student acceptance.

\subsection{Partial hypothesis test of self-placement towards a student acceptance level}

The third hypothesis to be tested is the effect of self-placement on the level of student acceptance. Based on the test results obtained by the value of $t_{\text {count }}$ of 2.530 with significant value (p-value) equal to 0.008 . Because $t_{\text {count }}(2.530)>t_{\text {table }}(2.048)$ then rejects $(H 0)$ and accepts the research hypothesis (H1) so that with a confidence level of $95 \%$ it can be concluded that self-placement has a significant effect on the level of student acceptance.

\subsection{Simultaneous Testing (Test F)}

The overall test (simultaneous) is done to prove whether there is influence from at least one independent variable on the non-independent variable. Based on the calculation, the calculated $\mathrm{F}$ value is 13.188 , by taking a significant level $\alpha$ of $5 \%$, then from the distribution table $F$, the $F_{\text {table }}$ value is obtained at 3.34. Because $F_{\text {count }}>F_{\text {table }}$ is $13.188>3.092$, H0 is rejected, meaning that simultaneously there is a significant influence between verbal ability and self-placement on the level of student acceptance. The results of the simultaneous hypothesis testing above are supported by the results of the assessment of the adjusted coefficient of determination (adjusted R2) which is equal to 0.466 or $46 \%$. while explaining the influence of variables outside the model, namely 1 - adjusted R $2=0.466$ or $46.6 \%$.

\subsection{Model Testing}

In the path analysis method, to find a causal relationship or influence of research variables, the correlation matrix of the dependent variable and the independent variable are first calculated. The partial determination coefficient is known that the effect of verbal ability on self-placement $(\mathrm{X} 1 \rightarrow \mathrm{X} 2)$ is equal to 0.776 in a positive direction. This value shows that the effect of self-placement has an influence on the level of student acceptance partially is equal to $77.6 \%$. The value of the influence of verbal ability on the level of student acceptance $(\mathrm{X} 1 \rightarrow \mathrm{Y})$ is 0.758 in a positive direction. This value shows that verbal ability gives influence 
to the level of student acceptance partially is equal to $75.8 \%$. The value of the effect of selfplacement on the level of student acceptance $(\mathrm{X} 2 \rightarrow \mathrm{Y})$ is similar to 0.751 in a positive direction. This value shows that self-placement influences the level of partial student admission of $75.1 \%$. The R2 value of $0.691^{\mathrm{a}}$ shows that verbal ability and self-placement influence the level of simultaneous student acceptance (overall) is $69.1 \%$. The results of data processing show the analysis of the correlation value partially or simultaneously is very strong and shows the influence of determination partially and simultaneously strongly, which can be illustrated in the figure as follows:

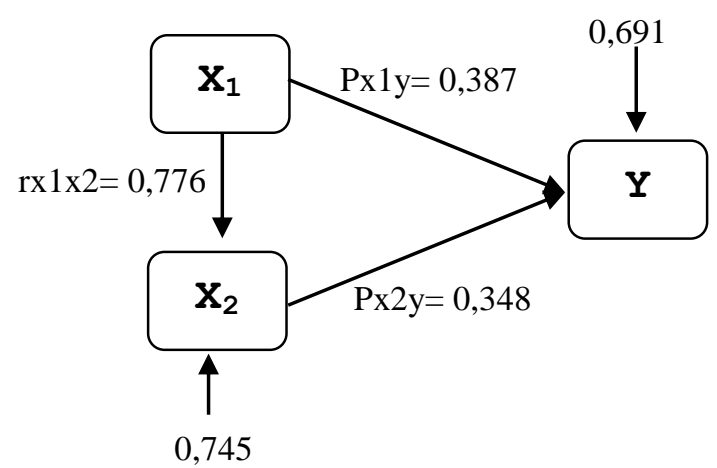

Fig.1. Structural Model correlation of verbal abilities and self-placement towards student acceptance level

Based on the path diagram (path diagram) in the picture above, structural equations can be obtained as follows:

The structural model I:

$\mathrm{X} 2=\mathrm{rx} 1 \mathrm{x} 2 \mathrm{X} 1+\varepsilon_{1}$

$=0.776 \mathrm{X} 1+0.745 \varepsilon_{1}$

Structural model II:

$\mathrm{Y}=\mathrm{P}_{\mathrm{X} 1 \mathrm{Y}} \mathrm{X} 1+\mathrm{P}_{\mathrm{X} 2 \mathrm{Y}} \mathrm{X} 2+\varepsilon_{2}$

$=0.387 \mathrm{X} 1+0.348 \mathrm{X} 2+0.691 \varepsilon_{2}$

From the picture above, we can also calculate the direct and indirect effects. The calculation is as follows:

The effect of verbal ability on the level of student acceptance consists of direct effects and indirect effects.

$\mathrm{DE}_{\mathrm{X} 1 \rightarrow \mathrm{Y}}=\left(\mathrm{P}_{\mathrm{X} 1 \mathrm{Y}}\right)^{2} \times 100 \%$

$\mathrm{DE}_{\mathrm{X} 1 \rightarrow \mathrm{Y}}=(0.387)^{2} \times 100 \%$

$\mathrm{DE}_{\mathrm{X} 1 \rightarrow \mathrm{Y}}=14.98 \%$

Direct influence is $14.29 \%$.

$\mathrm{IE}_{\mathrm{X} 1 \rightarrow \mathrm{Y}(\text { via } \mathrm{X} 2)}=\left(\mathrm{P}_{\mathrm{X} 1 \mathrm{Y}} \times \mathrm{x}_{\mathrm{X} 1 \mathrm{X} 2} \times \mathrm{P}_{\mathrm{X} 2 \mathrm{Y}}\right) \times 100 \%$

$\mathrm{IE}_{\mathrm{X} 1 \rightarrow \mathrm{Y}(\mathrm{viaX} 2)}=(0.387 \times 0.776 \times 0.348) \times 100 \%$

$\mathrm{IE}_{\mathrm{X} 1 \rightarrow \mathrm{Y}(\text { via } \mathrm{X} 2)}=10.45 \%$

Indirect influence is $10.45 \%$. $25.43 \%$

The effect of total verbal ability on student acceptance rates is: $14.98 \%+10.45 \%=$

The influence of self-placement on the level of student acceptance consists of direct effects.

$\mathrm{DE}_{\mathrm{X} 2 \rightarrow \mathrm{Y}}=\left(\mathrm{P}_{\mathrm{X} 2 \mathrm{Y}}\right)^{2} \times 100 \%$ 
$\mathrm{DE}_{\mathrm{X} 2 \rightarrow \mathrm{Y}}=(0.348)^{2} \times 100 \%$

$\mathrm{DE}_{\mathrm{X} 2 \rightarrow \mathrm{Y}}=12.11 \%$

The direct effect is $12.11 \%$. Together, verbal abilities and self-placement can influence student acceptance rates of $37.54 \%$ and the remaining $62.46 \%$ is influenced by other factors.

\section{Conclusion}

The level of student acceptance of self-placement and verbal ability is linear. The verbal ability has a significant effect on self-placement. Verbal ability has a significant impact on student acceptance. Good verbal ability will affect self-placement and self-acceptance. The results showed that self-placement had a substantial effect on the level of student acceptance. Simultaneously there is a significant influence between verbal ability and self-placement towards the level of student acceptance. This value shows that the effect of self-placement has an influence on the level of student acceptance partially is equal to $77.6 \%$. This value indicates that verbal ability gives control to the level of student acceptance partly is equal to $75.8 \%$. This value shows that self-placement has an influence on the level of student acceptance partially is equal to $75.1 \%$. Verbal ability and self-placement influence the level of simultaneous student acceptance (overall) at $69.1 \%$.

\section{Acknowledgments}

We want to thank the research institution that has supported the research activities was being carried out correctly. We thank researchers who are members of the community of educational science researchers who have collaborated well in this study.

\section{References}

[1] D. Ronda and Y. Salong, "Analisis Peran Teori Komunikasi Untuk Mencapai Tujuan Khotbah Yang Komunikatif Di Gereja Kibaid Klasis Makassar,” Jurnal Jaffray, vol. 10, no. 1, p. 174, Apr. 2012.

[2] M. D. Andrew, C. D. Cobb, and P. J. Giampietro, "Verbal Ability and Teacher Effectiveness," Journal of Teacher Education, vol. 56, no. 4, pp. 343-354, Sep. 2005.

[3] M. D. Andrew, C. D. Cobb, and P. J. Giampietro, "Verbal Ability and Teacher Effectiveness," Journal of Teacher Education, vol. 56, no. 4, pp. 343-354, Sep. 2005.

[4] G. Andreou *, P. Agapitou, and A. Karapetsas, "Verbal skills in children with ADHD," European Journal of Special Needs Education, vol. 20, no. 2, pp. 231-238, May 2005.

[5] D. Blakesley, "Directed Self-Placement in the University," vol. 25, no. 3, p. 32, 2002.

[6] A. H. Maslow and R. Frager, Motivation and personality, 3rd ed. New York: Harper and Row, 1987.

[7] L. A. Hjelle and D. J. Ziegler, Personality theories: basic assumptions, research, and applications, 3rd ed. New York: McGraw-Hill, 1992.

[8] S. B. Kaufman, "Self-Actualizing People in the 21st Century: Integration with Contemporary Theory and Research on Personality and Well-Being," Journal of Humanistic Psychology, p. 002216781880918 , Nov. 2018.

[9] O. Kuprieieva, "Psychological Characteristics of Self-Realization of Students with Disabilities," Social Welfare: Interdisciplinary Approach, vol. 2, no. 5, pp. 64-73, Apr. 2016.

[10] M. Tolong, "Strategi Komunikasi Sekolah Tinggi Theologia Jaffray Terhadap Masyarakat Sekitar," Jurnal Jaffray, vol. 8, no. 2, pp. 5-22, Oct. 2010. 
[11] D. L. Streiner, "Finding Our Way: An Introduction to Path Analysis," Can J Psychiatry, vol. 50, no. 2, pp. 115-122, Feb. 2005.

[12] H. W. Lilliefors, "On the Kolmogorov-Smirnov Test for Normality with Mean and Variance Unknown," Journal of the American Statistical Association, vol. 62, no. 318, pp. 399-402, Jun. 1967. 